\title{
COB BORER MUSSIDIA NIGRIVENELLA RAGONOT (LEPIDOPTERA: PYRALIDAE) OF MAIZE IN IVORY COAST. II - ECOLOGICAL DATA
}

\author{
P. MOYAL and M. TRAN \\ ORSTOM-IDESSA, B. P. 1434, Bouké, Côte D'Ivoire
}

(Received 16 July 1990)

\begin{abstract}
The larvae of Mussidia nigrivenella Ragonot, attack various fruits; it is the main maize cob borer in Ivory Coast. The development of attack during the cultivation, the behaviour of larvae in the field, the spatial distribution of eggs and larvae, the mortality of pre-imaginal instars and the annual fluctuations of populations are considered in this paper. This insect may represent an economical problem for seed producers in the south of the savannah area of Ivory Coast where its density exceeded 14 insects per cob, at harvest in 1984, whereas the risk of cob damaging by Mussidia nigrivenella appears to be very weak in the north and west of this region.
\end{abstract}

Key Words: Lepidoptera, Pyralidae, Mussidia nigrivenella, cob borer, dynamics of populations, Ivory Coast

\begin{abstract}
Résumé-Mussidia nigrivenella Ragonot, dont les larves attaquent divers fruits, est le principal ravageur de l'épi de maïs en Côte d'Ivoire. Sont étudiés dans cet article l'évolution des attaques au cours d'un cycle de culture, le comportement des larves au champ, la distribution spatiale des pontes et des larves, la mortalité des stades pré-imaginaux et les fluctuations annuelles des populations. Il est souligné que ce lépidoptère, dont la densité de population a dépassé, en 1984, 14 insectes par épi à la récolte dans le sud-est de la zone des savanes, représente une menace pour les.producteurs de semence de maïs dans le sud de la zone des savanes de la Côte d'Ivoire, alors que dans le nord et l'ouest le risque d'attaque de l'épi de maïs est très faible.
\end{abstract}

\section{INTRODUCTION}

Mussidia nigrivenella Ragonot is a fruit pest of crops; it completed development during postharvest storage. Its larvae have been mentioned in cocoa-pods and in maize cobs. More rarely this pest has been found in cotton capsules (Buyckx, 1962; Ghesquière, 1923; Staeubli, 1977), in the nut of the shea butter tree, Vitellaria paradoxa (Sorauer, 1925; Vuillet, 1912; Zacher 1922a, b), in the fruits of Ficus spp. (Le Pelley, 1959), Phasoelus funatus (Smith, 1965), and Sphenostylis stenocarpa (Nonveiller, 1984).

Stocks of various grains are also attacked by $M$. nigrivenella: cacao beans imported into Europe
(Evans, 1952; Potter, 1931; Varshalovich, 1975), seeds of Canavalia sp. and of beans (Buyckx, 1962; Le Pelley, 1959), soja beans (Moyal, 1988a) and maize grains, at the beginning of storage (Ratnadass, 1987; Tran, 1987). However, $M$. nigrivenella cannot be considered as a stock insect of maize since it generally just completes its development started in the field.

The geographic distribution of this pest is limited to Africa south of Sahara (Moyal and Tran, 1989).

The purpose of this paper is to describe the development of the population of M. nigrivenella in the maize field and its importance as cob borer of maize in the savannah area of Ivory Coast.

\section{O.R.S.T.0.M. Fonds Documentaire}




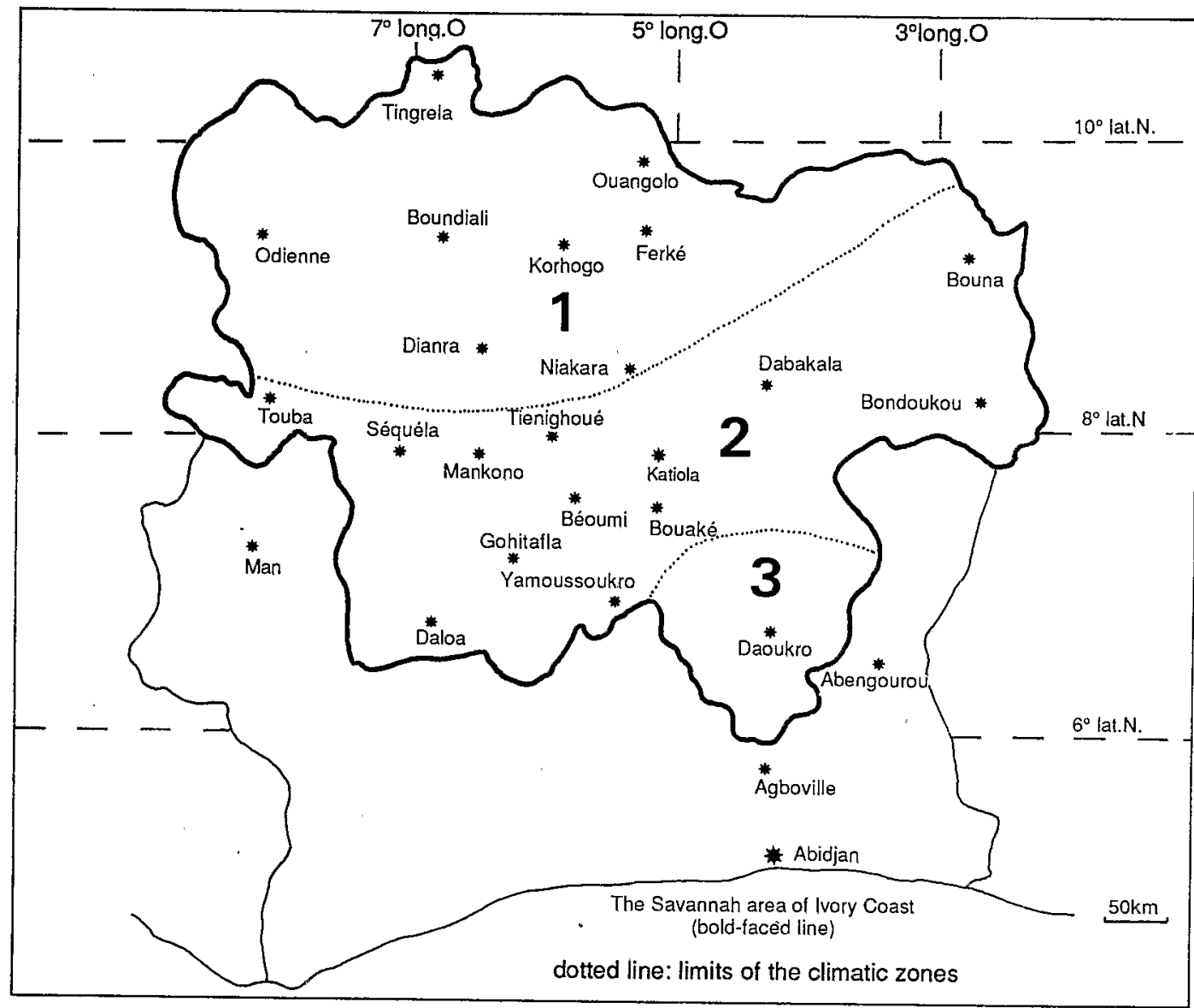

Fig. 1. Map of Ivory Coast with the limits of the savannah area (bold faced line) and of the climatic zones of this region (dotted lines): 1 . northern climatic zone (two seasons); 2. central climatic zone (transition);

\section{MATERIALS AND METHODS}

This study has been realized in the savannah area of Ivory Coast. This region, $188,000 \mathrm{~km}^{2}$ wide, can be divided into three climatic zones (Fig. 1): The northern one, with a dry season from October to May, and a rainy season with a peak in August; the southern one with two dry seasons (the most important from December to February, the shorter in August-September) and two rainy seasons; a transition zone between the two, where climate varies with the maximum latitude reached by the inter tropical front. If it is a high latitude, this zone will have four seasons in a year, if not the climate will be similar to that of the northern zone.

Pluviometry has been regularly decreasing for the 4 years of this study (1981-1984), with a minimum in 1983, where the drought destroyed many food crops in the south of the savannah area. Then in 1984, the pluviometry again reached around the average level.
Sampling was made in various localities, either on observation fields or on control plots in the course of insecticide trials.

In most cases Composite Jaune de Bouaké (CJB) was the variety used. It is the most commonly used improved variety in peasants' fields (CIDT, 1984). The duration of its cycle from sowing to harvest is $100-105$ days. Its plants are high (more than $3 \mathrm{~m}$ ). Its production is on average $4000 \mathrm{~kg} / \mathrm{ha}$ during trials and its maximum yield is $6200 \mathrm{~kg} / \mathrm{ha}$ (IDESSSA, 1982). The study of the population development during one season has also been done with two other varieties with quicker cycle: Maïs Témoin Station (MTS), sowing-harvest (95-100 days) and Composite Dahomey (CD), (sowing-harvest 75-80 days).

Harvested cobs were dissected after shucks and silks were observed in order to look for eggs. Sampling was made at random, either in the whole of the field (in the case of observation fields), or on two rows of maize in the plots of insecticide trials. 
It was made every 3-7 days for studying the development of populations during one growing season, whereas a single sample was taken at harvest to establish the level of populations in various localities of the savannah area. Samples were of at least 50 cobs.

Fitting of the distribution of eggs and larvae to mathematical distributions was made on HewlettPackard $41 \mathrm{CV}$ pocket computer (Moyal, 1988a).

\section{RESULTS}

Development of infestation by M. nigrivenella during a growing season (Figs 2 and 3)

The number of eggs is an estimation of the actual number of eggs laid, taking into consideration the duration of hatching and the time between two samples.
The first egg-laying occurred 60 days after emergence. Progression of egg-laying is strong from 70 days after emergence for MTS and CJB, and as early as the 60th day after emergence for $C D$. No variety seems to have a particular attractivity: MTS, on which more eggs are found in Yamoussoukro, is less attacked in Bouaké (this study was made on large non-randomized plots).

The number of larvae and pupae obtained after dissecting cobs was far more less than the number of eggs laid (see later the study of mortality); only larvae older than the third instar were taken into account. It is very difficult to find $\mathrm{L} 1$ and $\mathrm{L} 2$ instars, hidden in the grains or cob, without any obvious damage and especially on young cobs that cannot be shelled.

The first pupae are found as early as the 75th day after emergence in Yamoussoukro and only at 90-100 DAE in Bouaké. This last figure indicates

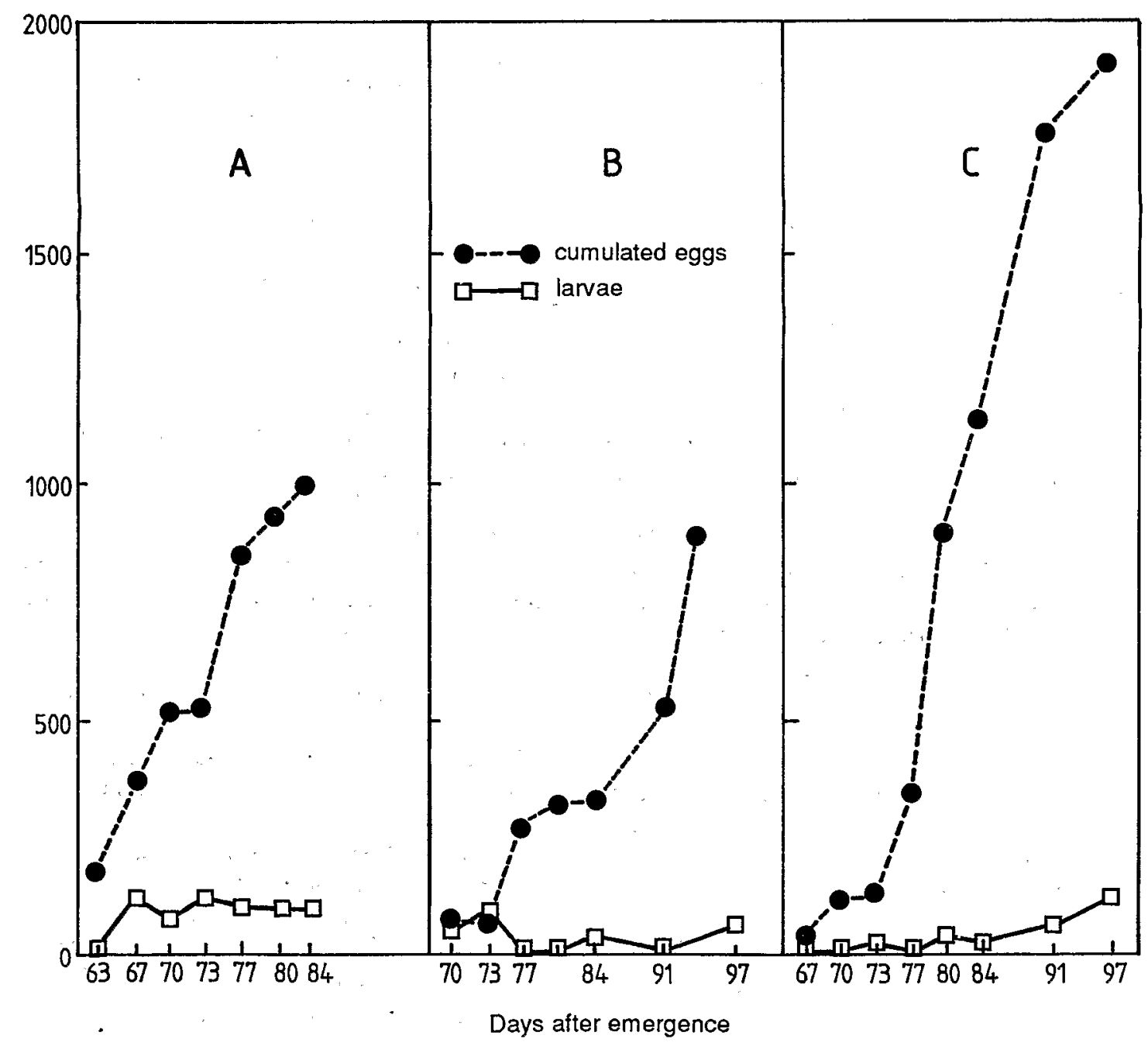

Fig. 2. Evolution of the cumulated number of eggs (solid line) and of the number of larvae (dotted line) of $M$ ussidia nigrivenella in 100 cobs in Yamoussoukro (1981): (A) variety CD; (B) variety CJB; and (C) variety MTS. 


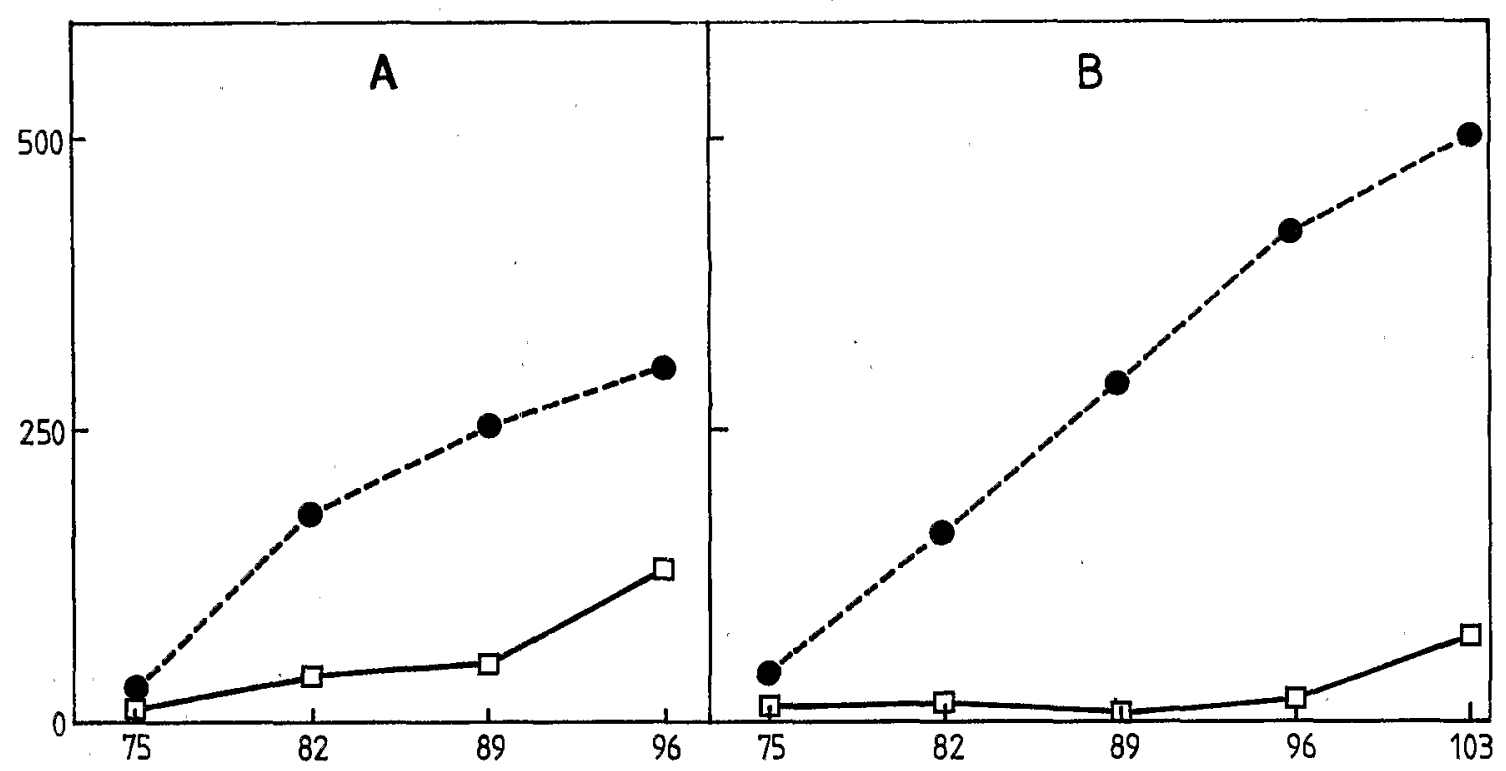

Days after emergence

Fig. 3. Evolution of the cumulated number of eggs (solid line) and of the number of larvae (dotted line) of Mussidia nigrivenella in 100 cobs in Bouaké (1981): (A) variety MTS; and (B) variety CJB.

durations of cycles of development similar to those obtained on an artificial diet (Moyal and Tran, 1991).

\section{Larval behaviour in the field}

Egg-laying takes place on the cob or just below (Moyal and Tran, 1989). After hatching, the larvae wander through the cob, in no particular direction. If they reach the silks, they penetrate into the cob where they will stay until the end of pupation. Only the initial first instar stage is lived outside the cob. Once the larvae are under the shucks, they stay there even when overpopulated. Cannibalism may then occur, but no dispersal as occurs in the case of Eldana saccharina Walker, a maize stem and cob borer.

At pupation, the larva bores through the shucks to create the adult's exit, weaves a cocoon and turns into chrysalis. No diapause phase has been observed.

Since there was heterogeneity of frequencies when the density of insects per cob is increasing, fitting to mathematical distributions was made after arranging in groups of ( 0 egg or insect per cob, 1 to 4,5 to 8 , etc.).

The best fit of distribution of eggs is a negative binomial distribution with a low $k$, whereas that of larvae is a Poisson distribution or a negative binomial with a relatively high $k$ (Table 1 ).

The mortality of eggs due to parasitism (by Trichogrammatids or Scelionids) and at rearing in the laboratory were distinguished. The mortality of the young instars L1 and L2 was deducted by difference between the number of older larvae found at dissection of cobs and the number of corresponding larvae hatched (because of the great difficulty to find young larval instars when dissecting cobs) (Table 2).

No larval nor pupal parasite was found; mortality of insects found through dissection was that not due to parasites.

\section{Annual fluctuations of populations (Figs 4 to 7 )}

The density of population is determined for the main growing season (sowing in June) for the years 1981 to 1984).

The level of population is fairly similar for the first 3 years and higher in 1984 .

The northern and western regions are less attacked, whereas the density of population increased towards the south and southeast of the savannah area; in Daoukro, at harvest in 1984, the density was more than 14 larvae of $M$. nigrivenella per cob. 
Table 1. Fitting the spatial pattern for eggs and larvae of Mussidia nigrivenella to mathematical distributions

\begin{tabular}{|c|c|c|c|c|c|c|c|}
\hline \multirow[t]{2}{*}{ Locality } & \multirow[t]{2}{*}{ Variety } & \multicolumn{3}{|c|}{ Fitting for eggs } & \multicolumn{3}{|c|}{ Fitting for larvae } \\
\hline & & $\begin{array}{l}\text { Number of } \\
\text { eggs } / 100 \text { cobs }\end{array}$ & $\begin{array}{l}\text { Ma } \\
\text { dist }\end{array}$ & $\begin{array}{l}\text { atical } \\
\text { ion* }\end{array}$ & $\begin{array}{l}\text { Number of } \\
\text { larvae/ } 100 \text { cobs }\end{array}$ & $\begin{array}{l}\text { Mathen } \\
\text { distribu }\end{array}$ & $\begin{array}{l}\text { tical } \\
\text { on } *\end{array}$ \\
\hline \multirow[t]{8}{*}{ Bouaké } & \multirow[t]{2}{*}{ MTS } & \multirow[t]{2}{*}{62} & $\mathrm{BN}$ & & 138 & $P$ & \\
\hline & & & $k$ & 0.53 & & & \\
\hline & \multirow[t]{2}{*}{ MTS } & \multirow[t]{2}{*}{33} & $\mathrm{BN}$ & & & & \\
\hline & & & $k$ & 0.60 & & & \\
\hline & \multirow[t]{2}{*}{ CJB } & \multirow[t]{2}{*}{128} & $\mathrm{BN}$ & & & & \\
\hline & & & $k$ & 0.05 & & & \\
\hline & \multirow[t]{2}{*}{ CJB } & \multirow[t]{2}{*}{71} & $\mathrm{BN}$ & & 72 & $\mathrm{BN}$ & \\
\hline & & & $k$ & 0.07 & & $k$ & 0.71 \\
\hline \multirow[t]{12}{*}{ Yamoussoukro } & \multirow[t]{2}{*}{ MTS } & \multirow[t]{2}{*}{575} & $\mathrm{BN}$ & & 108 & $\mathrm{BN}$ & \\
\hline & & & $k$ & 0.66 & & $k$ & 1.40 \\
\hline & \multirow[t]{2}{*}{ MTS } & \multirow[t]{2}{*}{148} & $\mathrm{BN}$ & & & & \\
\hline & & & $k$ & 0.19 & & & \\
\hline & \multirow[t]{2}{*}{ CJB } & \multirow[t]{2}{*}{283} & $\mathrm{BN}$ & & 60 & $P$ & \\
\hline & & & $k$ & 0.23 & & & \\
\hline & \multirow[t]{2}{*}{$\mathrm{CJB}$} & \multirow[t]{2}{*}{363} & $\mathrm{BN}$ & & & & \\
\hline & & & $k$ & 0.36 & & & \\
\hline & \multirow[t]{4}{*}{$\mathrm{CD}$} & \multirow[t]{2}{*}{259} & $\mathrm{BN}$ & & 80 & $P$ & \\
\hline & & & $k$ & 0.22 & & & \\
\hline & & \multirow[t]{2}{*}{180} & $\mathrm{BN}$ & & & & \\
\hline & & & $k$ & 0.10 & & & \\
\hline \multirow[t]{2}{*}{ Beoumi } & \multirow[t]{2}{*}{$\mathrm{CJB}$} & & & & 480 & $\mathrm{BN}$ & \\
\hline & & & & & & $k$ & 6.03 \\
\hline \multirow[t]{3}{*}{ Daoukro } & \multirow[t]{3}{*}{$\mathrm{CJB}$} & & & & 360 & $P$ & \\
\hline & & & & & 1430 & $\mathrm{BN}$ & \\
\hline & & & & & & $k$ & 11.6 \\
\hline
\end{tabular}

$* \mathrm{BN}=$ Negative binomial distribution with indication of the value of parameter $k$. $P=$ Poisson distribution.

Table 2. Mortality of the pre-imaginal instars of Mussidia nigrivenella

\begin{tabular}{|c|c|c|c|c|}
\hline Locality & Instar & Initial & \multicolumn{2}{|c|}{ Percentage of mortality } \\
\hline \multirow[t]{6}{*}{ Yamoussoukro } & Egg & 1066 & Parasitism & 15.7 \\
\hline & & & Rearing mortality & 10.0 \\
\hline & $\mathrm{L} 1+\mathrm{L} 2$ & 809 & Infered mortality & 92.4 \\
\hline & L3 to & & & \\
\hline & pupa & 61 & & 8.1 \\
\hline & & & Total mortality & 94.8 \\
\hline \multirow[t]{5}{*}{ Bouaké } & Egg & 389 & Parasitism & 1.7 \\
\hline & & & Rearing mortality & 2.9 \\
\hline & $\mathrm{L} 1+\mathrm{L} 2$ & 371 & Infered mortality & 70.4 \\
\hline & L3 to pupa & 110 & 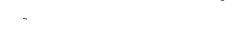 & 9.1 \\
\hline & & & Total mortality & 74.3 \\
\hline
\end{tabular}




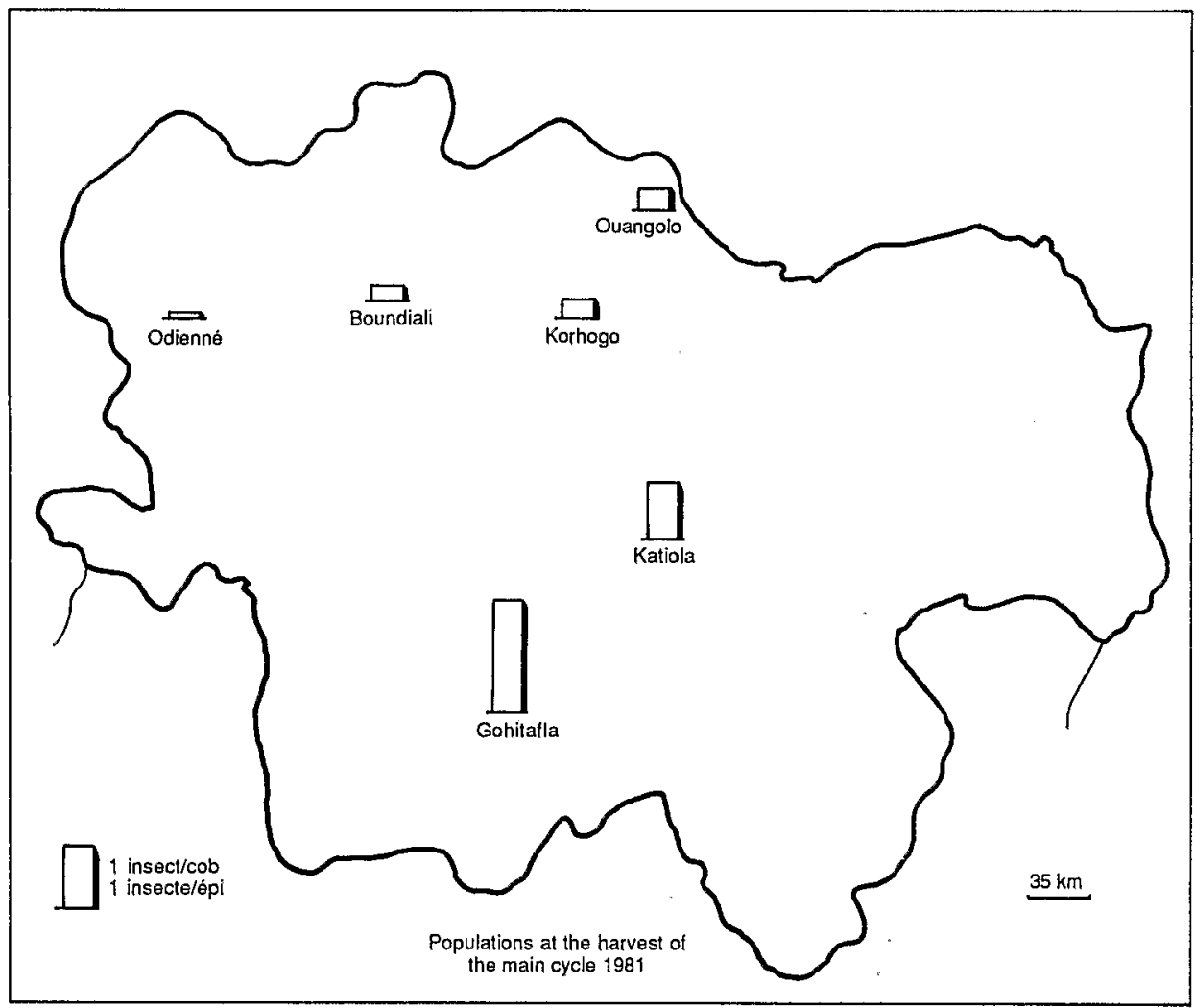

Fig. 4. Population density of Mussidia nigrivenella at the harvest of the main cycle in 1981.

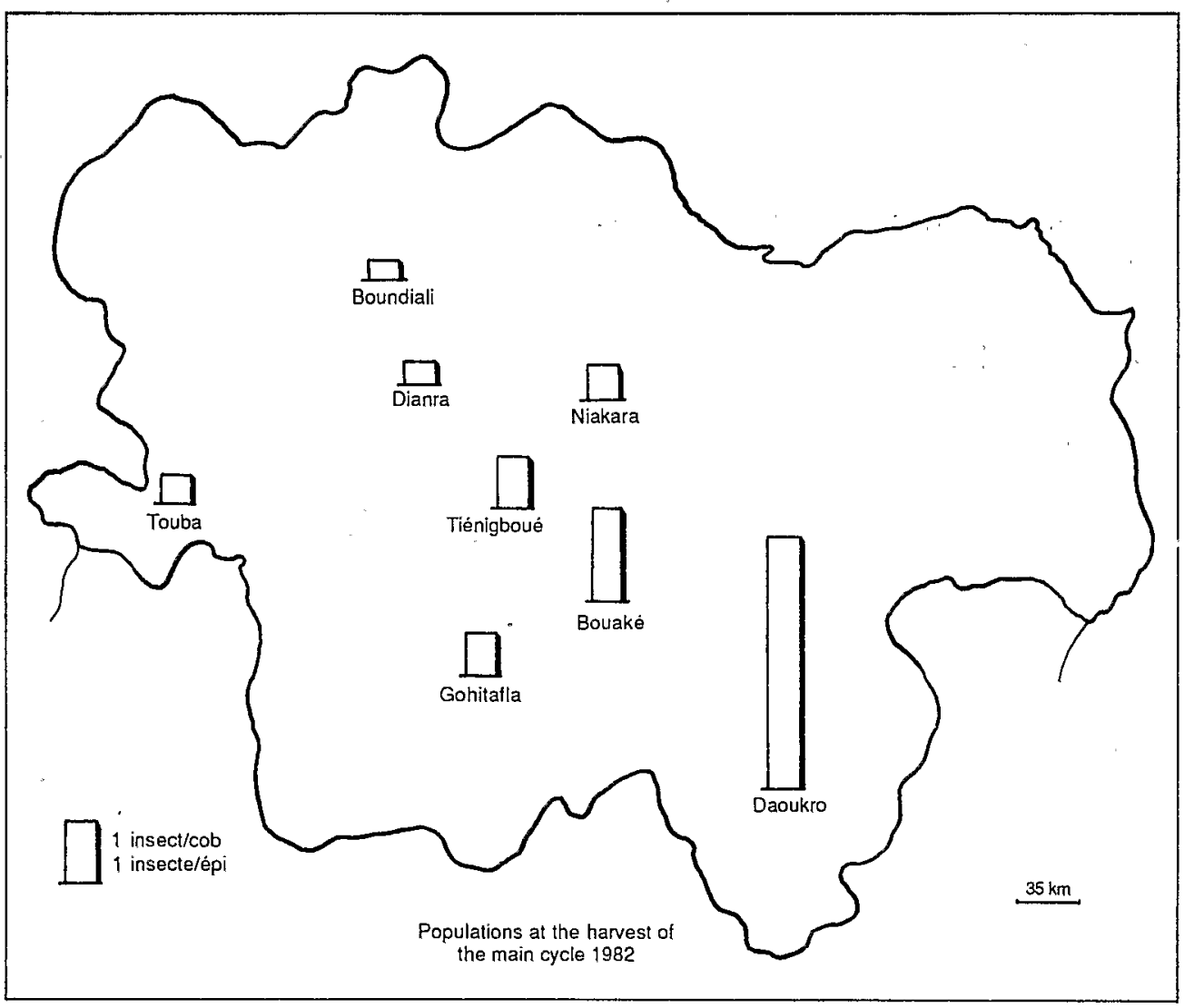

Fig. 5. Population density of Mussidia nigrivenella at the harvest of the main cycle in 1982. 


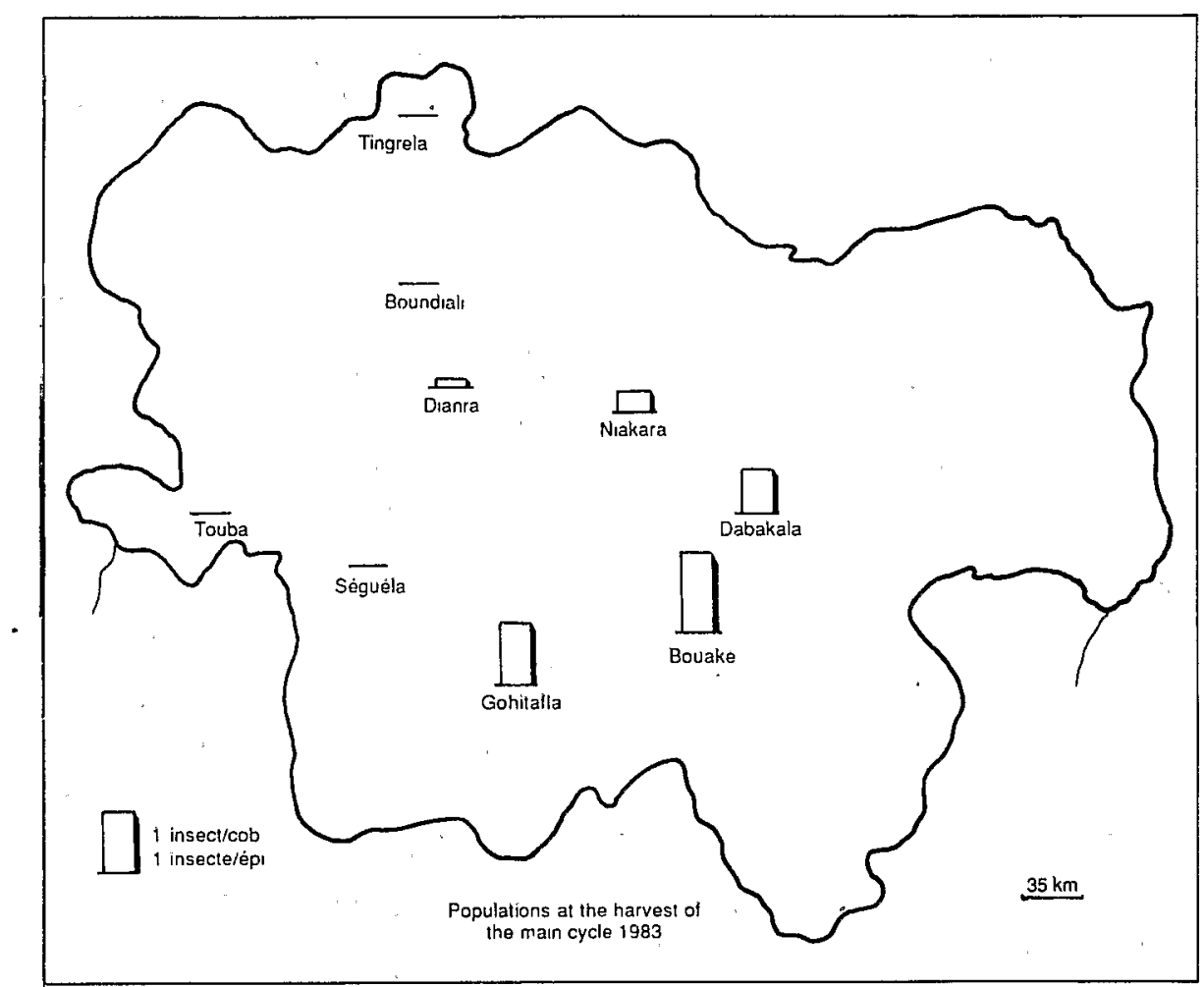

Fig. 6. Population density of Mussidia nigrivenella at the harvest of the main cycle in 1983.

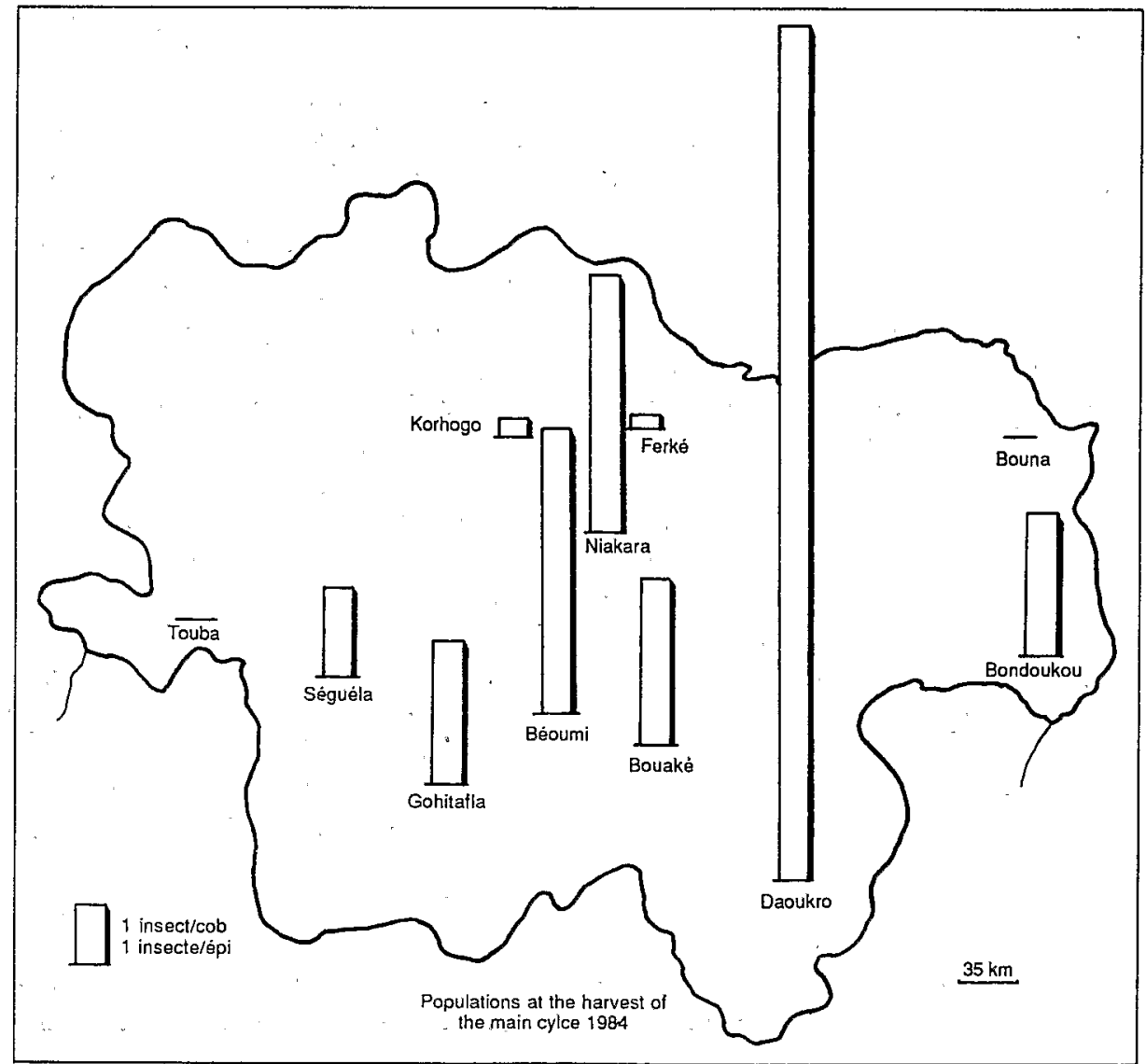

Fig. 7. Population density of Mussidia nigrivenella at the harvest of the main cycle in 1984. 


\section{DISCUSSION}

Results mentioned above show the importance of $M$. nigrivenella as a pest of maize cob in the savannah area of Ivory Coast. It is the main cob borer (Moyal, 1988a) with fairly high population densities in the southern part of the region.

This insect is sheltered under the shucks as early as the second larval instar and its mortality occurs at the early stages, egg and $\mathrm{L} 1$.

Only larvae that have penetrated into the cob during the first day after hatching may live, since a newly hatched larva cannot survive more than 1 day without feeding.

The egg laying occurs on the shucks, but no particular stimulus seems to attract the newly hatched larvae towards the silks where they can enter the cob. Their mortality is then high, from 70 to $90 \%$, and may be explained by the fact that $M$. nigrivenella is an African polyphagous insect, not specialized in attacking a plant native of America.

Egg mortality varies with parasitism, density and climatic factors. The percentage of eggs parasitized increases with the density of eggs, which is itself dependent on relative humidity. In the course of this study, in a given place, egg-laying was important when relative humidity was high and weak when it was low (Moyal, 1988a).

The distribution of eggs is generally very aggregative: the best fit to mathematical distributions is a negative binomial with a low $k$, which shows a high level of aggregation (Eliott, 1971). The rare cases when the best fit is a Poisson distribution are those of low egg density, which meets Eliott's opinion (1971) that Poisson distributions fit low population densities.

The larvae distribution are best fitted either to negative binomial distributions with a high $k$ which then are tending to Poisson distributions (Southwood, 1978).

This random distribution may be explained by two factors: The dispersion of newly hatched larvae, which, however, is certainly low, because of the weakness of this instar, and above all, successive egg-layings at random in the course of time, egg-layings that are themselves aggregative at a given time (larvae and pupae at the end of the season originating in eggs laid during several weeks).

The density of population is very weak in the north and in the west and becomes stronger and stronger towards the south and the east. This phenomenon is frequently met in various crops (Moyal, 1988b).
The same observation can be made every year in spite of fluctuations that may be fairly important from 1 year to another (particularly in 1984, where the level of populations was high after a very dry 1983 year).

The importance of relative humidity and of pluviometry particularly in the egg-laying may partly explain this situation: When rains are beginning early in the year the first generation can be more important and then, during the second rainy season pullulations may occur.

$M$. nigrivenella is a cab borer, the densities may be very important, particularly in the southern part of the savannah area of Ivory Coast. If the yield loss due to this pest is fairly weak (Moyal, 1988a), however, the percentage of grains attacked per cob, and then worthless for sowing, is high, 15-20\% with five insects per cob.

Such loss levels may justify use of control methods against $M$. nigrivenella which in the south of the savannah area of Ivory Coast is a real economic risk for seed producers.

\section{REFERENCES}

Buyckx E. J. E. (1962) Précis des maladies et des insectes nuisibles rencontrés sur les plantes cultivée au Congo, Rwanda et au Burundi. Publications de l'Institut National pour l'Etude Agronomique du Congo (INEAC), Hors série.

Compagnie Ivoirienne pour le Dévéloppement du Textile (CIDT) (1984) Rapport annuel d'activité, Bouaké.

Elliot J. M. (1971) Some methods for the statistical analysis of samples of benthic invertebrates. Freshwater biological association. Sci.publ.25, pp. 1-148.

Evans J. W. (1952) The Injurious Insects of the British Commonwealth. London Commonwealth Institute of Entomology.

Ghesquière J. (1923) Contribution à l'étude éthologique des Laemophloeus. Rev. Zool. Africaine 10, 216-218.

Institut des Savanes (IDESSA) (1982) Varietés de Maïs Recommandées en Côte d'Ivoire. Ministère de la Recherche Scientifique de Côte d'Ivoire, Abidjan.

Le Pelley R. H. (1959) Agricultural Insects of East Africa. East Africa High Commission, Nairobi, Kenya.

Moyal P. (1988a) Les foreurs du maïs en zone des savanes en Côte d'Ivoire. Collection Etudes et Thèses, Editions de l'ORSTOM, Paris.

Moyal P. (1988b) Crop losses due to insects in the 
savannah area of Ivory Coast: A review. Trop. Pest Manage. 34, 455-459.

Moyal P. and Tran M. (1989) Etudes morphologiques des stades pré-imaginaux des Lépidoptères foreurs du maïs en zone des savanes de Côte d'Ivoire. Ann. Soc. Entomol. France 25, 461-472.

Moyal P. and Tran M. (1991) Cob borer Mussidia nigrivenella (Lepidoptera, Pyralidae), of maize in Ivory Coast. I - Morphological and biological data (this Issue).

Nonveiller G. (1984) Catalogue des insectes du Cameroun d'intérêt agricole. Institut pour la protection des plantes. Mémoire 15, 100-101.

Potter C. (1931) A new moth introduced into England: Mussidia nigrivenella Ragonot (Phycitidae). Entomol. Mon. Mag. 1, 16, 678: 258.

Ratnadass A. (1987) Dynamique des populations d'insectes ravageurs des stocks de céréales en milieu villageois d'Afrique tropicale. Thèse de Docteur-Ingénieur de l'INAPG, Paris.

Smith P. R. (1965) A list of Lepidoptera associated with cocoa in West Africa with notes on identification and biology of species in Ghana, Ghana Acad. Sci. Tech. Bull. 9, 1-68.

Sorauer P. (1925) Handbuch der Pflanzenkrankheiten. Verlag, Berlin.

Southwood T. R. E. (1978) Ecological Methods. Chapman \& Hall, London.

Staeubli A. (1977) Contribution à l'étude de Cryptophlebia leucotreta (Meyrick) particulièrement au Bénin. Cot. et Fib. trop. 32, 325-349.

Tran M. (1987) Les Insectes Ravageurs des Stocks de Maïs et de Riz en Région Centre-ouest de Côte d'Ivoire (villages de Booda et Zooha). Multigraphie ORSTOM-IDESSA, Bouaké.

Varshalovich A. A. (1975) A little known pest of cacao beans. Zashchita Rastenii 2, 26.

Vuillet A. and Vuillet J. (1912) Notes sur les insectes nuisibles au Karité. Agriculture Pratique des Pays Chauds 2, 436-448.

Zacher F. (1922a) Schädlinge der Nutzpflanzen in West Sudan. Der Tropenpflanzer, Berlin 24, 97-108.

Zacher F. (1922b) Schädlinge der Nutzpflanzen in West Sudan. Der Tropenpflanzer, Berlin 24, 132-142. 